\title{
茨城県議会議事堂から県立図書館へ
}

\author{
小笠原 正 裕*
}

\section{1. 茨城県議会議事堂の概要}

茨城県水戸市三の丸, 歴史的雲囲気の残る旧県庁跡地 にある旧茨城県議会議事堂（以下，旧議事堂とする）は, 茨城会館を建て替えたもので 1970 年竣工（設計：茨城 県，日建設計＼cjkstart施工：竹中工務店）以来，1999 年 4 月 の県庁移転により新議事堂へと移るまでの約 30 年間県 政の中心としての役割を担ってきた。その建築意匠は, 内外装ともに，近代建築の一つの典型と言えるものである。

\section{2. 茨城県議会議事堂の改修への経緯}

旧議事堂の保存に関する検討として，1998 年に「茨 城県議会議事堂の耐震耐力等調查」がなされた。その内 容は, 耐震診断之躯体および設備の老朽化調査で, 図書 館への転用の可能性を挆るものであった。結果は, 既存 建物の良好な耐震性能之限界を迎えた設備寿命之が明ら かとなった。建物の老朽化については修綞可能な比較的 軽微なものと判明した。ただし, 大改造をしないで機能 転換するとはいえ，全面的な設備更新や老朽化したコン クリート面の補修, 間仕切り変更と図書館用設備導入に はさらなる検討が求められることとなった。もう一方で ソフト面として, 茨城県立図書館の将来像に関する検討 が必要となり，高山正也慶応大学教授を主宰者とする 「県立図書館機能充実のための調查研究会」が設置され た。研究内容は旧議事堂の活用を念頭に置いたものとは いえ，議事堂の持つ建築的なポテンシャルと空間の豊加 さを積極的に評価し，新図書館として再構築するための 示唆に富んだものであった。様々な検討の結果として, 県庁跡地は旧本庁と旧議事堂を祡政の象徴として転用・ 改修し, その他の建物は解体撤去, 敷地全体を公園とし て整備する事が決定された。

\section{3. 改修の基本方針}

旧議事堂を改修・再生させるにあたっては, 議事堂と しての「空間の記憶」を機能を満たしながら新図書館に いかに継承していくかが設計のメインテーマとなった。 旧議事堂の最も“議事堂らしさ”を感じさせる空間は, 3 層吹き拢けの議場への階段が象徽的に存在するエント ランスホールと自然光の降り注ぐ天井高 $12 \mathrm{~m}$ の議場で

* おがさわら・まさひろ/茨城県上木部 営繥課長
あった。改修の方法としてエントランスホールおよび議 場は極力手を入れず，往時のダイナミックな空間を残し， かつ議事堂当時の䨌囲気を感じられる空間とすることを 基本方針とした。

また, 建物構成としてはエントランスホールと視聴覚 ホールを中心に, 両翼 2 層にわたって開架室を配置し, 開架室となる部分の設備・内装は全面改修を行い, 図書 館機能を付加していくこととした。

\section{4. 設計・施工}

以上のような調查・研究の結果を受け1998 年末から 基本設計が始まり, 茨城県生涯学習課, 茨城県土木部営 繥課, 茨城県立図書館, 日建設計などを交え, より細部 にわたって茨城県立図書館のあり方および転用・保存の 方法が検討され, 更なる現場調查の後 1999 年に実施設 計が完了した。工事は2000 年 4 月に着工し, 現場段階 に扔いても図書館関係者との更なる討論を重ねながら工 事は進められ，2000 年 12 月に新茨城県立図書館は完成 をみることとなった（写真-1 参照）。

5. 建築物の設計内容

\section{1 建築計画について}

具体的な改修内容としては, $R C$ 打放しのエントラン スホール（写真-2参照）はサービスデスクとブラウジ ングとして使用されるため, 打放し面に吸音材をアルミ 型材で押觉るという吸音处理を行い，それ以外には手を

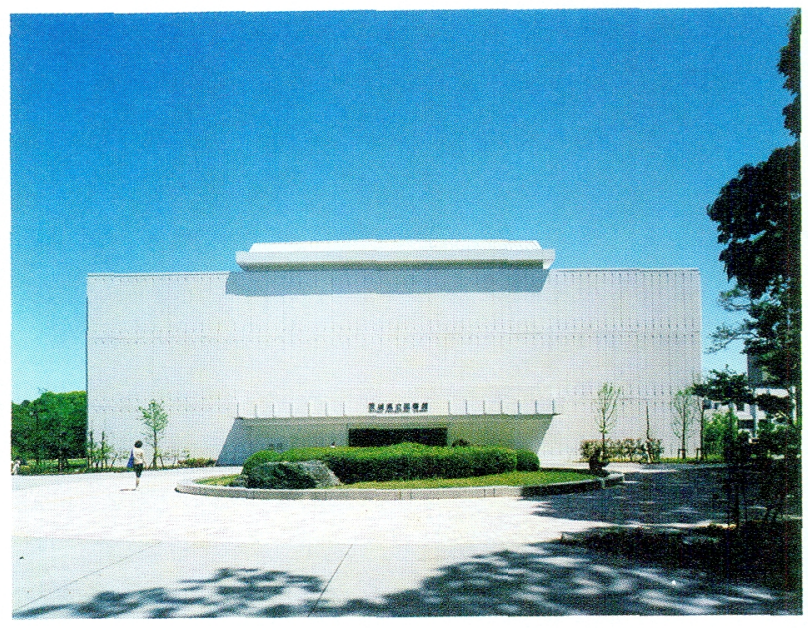

写真-1 茨城県立図書館の外観 


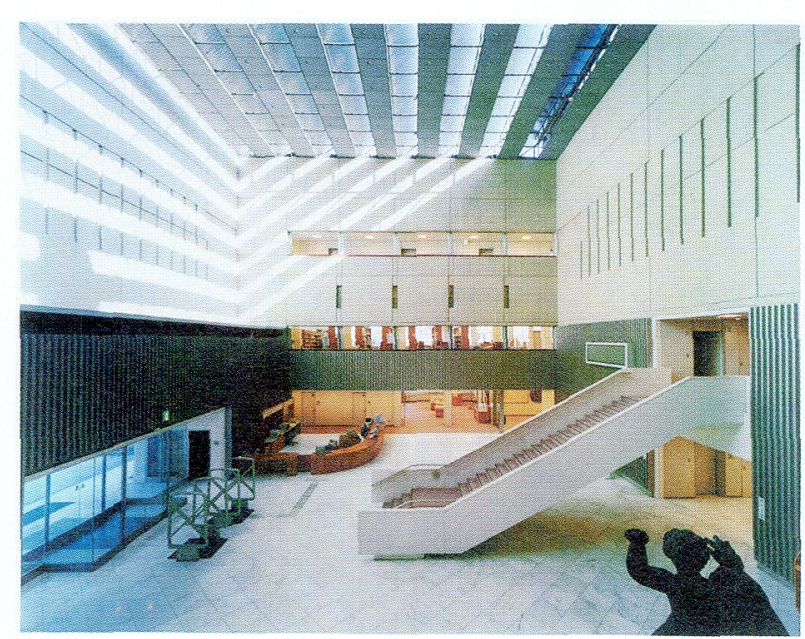

写真-2 エントランスホール内観

入れず，往時の雲讲気，素材感屯極力そのままとした。 また，利用法として議論が伯仲した議場は “視聴賞ホー ル兼閲覧室” として従来の空間を確保するという前提に 基づき，かつて選良の方々が県政を担った議員席をその まま使用した。傍聴席と記者席は取り壊しメイン出入口 の追加扔よび閲覧席の増設を行った。議長席廻りについ ては撤去し，大型映写スクリーンとステージを新設，通 常は閲覧室として使用し, 催事には視聴覚ホールとして 使用できる計画とした。両翼については既存の間仕切り をすべて撤去し, 各階奥行き約 $12 \mathrm{~m}$, 長さ約 $45 \mathrm{~m}$ のオー プンスペースを準備し，当初設計同様に図書館機能を合 理的に配置した。また, 茨城県立図書館は, 地域図書館 としての特色も強く持っており, 多くの来館者が予想さ れたため, 分かりやすく使いやすい施設をめざし，近づ きやすい1，2 階を来館者ゾーンと設定した。

3 階は一般利用者と職員との動線を分け, 事務室, 館 長室，会議室等のサービス関係諸室を配した。また，床 にはOAフロアを追加した。旧議事堂地下１階には駐 車場, 大会議室, 機械室, その他サービス諸室があった が，機械公を若干搪張した他はほとんどを閉架書庫とし た。旧大会議室は高い天井を生かし，将来的には積層書 庫とすることを想定している。これらにより図書館全体 として, 最大収蔵能力 76.5 万冊を確保している。また, 既存建物が大小さまざまな部屋を效率よく組み合わせた ものであったため建物内に数多くのレベル差が存在した。 改修設計においては，バリアフリー建築実現のために状 況に応じて，スロープ，段差解消機，エレベーター 1 基 を使い分けて追加設置し，バリアフリー対応を徹底した。

\section{2 構造計画について}

旧建物の耐震診断の結果，標準建物であるならば問題 ないが公共建築としての重要度係数を考慮した場合, 長 手方向に不足があると診断された。そこで, 機能上問題 のない耐震補強箇所を検討し, 地下 1 階の旧会議室（改 修後は閉架書庫）の壁面を增し打ちすることにより耐震 補強とした。また, 旧建物の床スラブの荷重条件が事務

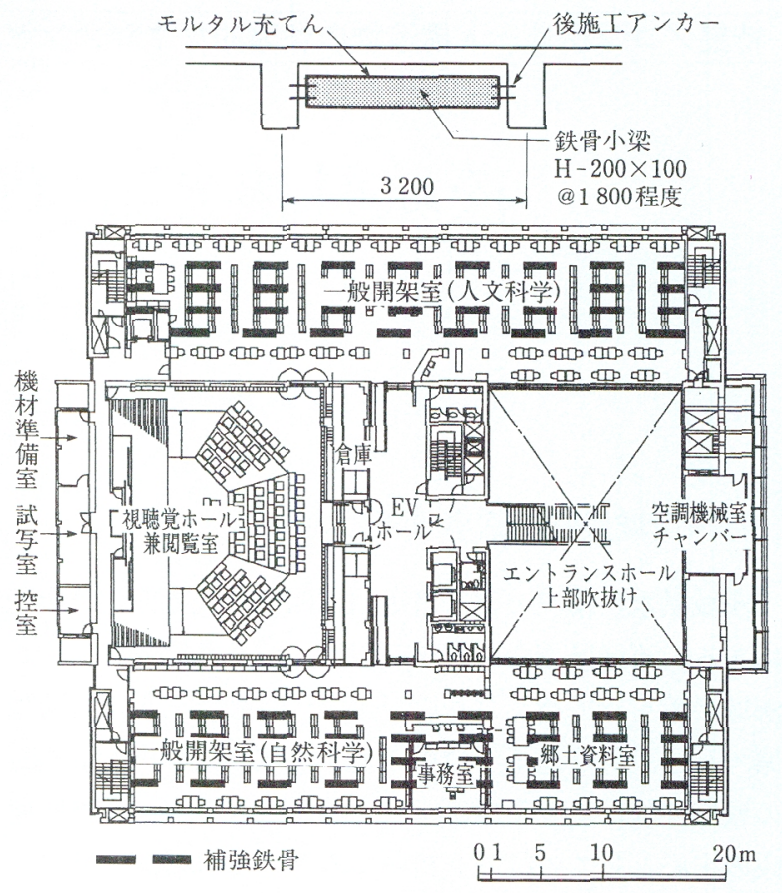

図-1構造補強模式図

所として想定されていたため，書架が載る部分について 床の補強が必要となった。2 階は利用形態を尊重してス ラブ下の大梁間に，地下 1 階については施工性を考えて 床上にH鋼を追加した（図-1参照）。

\section{3 設備計画について}

電気・空調・衛生設備とも一部を除きほとんどを更新 することとした。電気・通信設備は, 幹線の既存配管配 線を撤去し, 電気シャフトと天井内ケーブルラックを新 設し, 更に図書館に求められる最新の情報システムを導 入した。照明器具も十分な照度を取れるものに更新した。 空調設備のシステムは既存の方針を踏襲しながら，より 合理的な方法を検討し，機能搪張の改修を行った。衛生 設備工事についてもほとんどを撤去・新設としたが，施 設の性格上, 漏水刘策を徹底した。衛生器具は節水型の 使いやすいものを採用している。

\section{6. まとめ}

旧議事堂は「県政の記憶」を残すという理由と, 十分 な耐用年数を残していることから改修が実現した。当初 計画を進めるにあたっては, 全く用途の違う施設という ことから，合理的な改修計画が実現できるかは疑問の中 でのスタートであった。近代建築は機能に忠実に造られ ているため, 用途変化が起きると寿命が尽きると言われ てきた。しかし具体的な設計を行っていく上では意外に 屯, 議事堂から図書館への変身は実に自然に進んでいっ た。これは，旧議事堂が議事堂であっても限りなく「普 通」な空間として造られていたことと権威主義とは縁遠 い素直な外観であったからここく自然に図書館の顔とな り県民の「知の中心」となり得た。また，建物全体が空 間的に豊かに無理なく構成されていたことから新而震設 
計に置き換える際にも，部分的に壁厚を増した以外には 全く耐震改修をする必要がないほじ構造が合理的であった。 結果的に本改修により新茨城県立図書館は同規模の図 書館を新設するのに比へてて半額以下のコストで県立図書 館を整備することができた。ここれは,クライアントに対 してだけでなく社会に対しても，環境的に対しても大い に貢献していることになる。本計画は「近代建築の改修 のあり方」を示す一つの指針となるのではないかと考え
られる。

新茨城県立図書館は開館以来，取り立てた不具合もな く図書館として機能し続けている。図書館関係者および 県民の方々から大変好評を頂いており, 開館以来 2 年余 りで来館者数が 200 万人を超えるという賑わいを見せて いるところである。これは, 新茨城県立図書館が広く県 民に受け入れられ，定着した結果だと理解している。

\section{ICCRRR 2005-SCOPE OF CONFERENCE AND THEMES COVERED International Conference on Concrete Repair, Rehabilitation and Retrofitting}

1. 会 期：2005年 11 月 21 日 23 日

2. 場 所：Cape Town, South Africa

3. 締切日 (Submission of Abstracts)：2004 年 7 月 31 日

4. Topics:

Concrete durability aspects

- Causes and mechanisms of deterioration

Concrete transport mechanisms

Life-cycle assessments

Durability modelling and prediction

- Durability of structures in normal and aggressive environments

New and more durable types of concrete Deterioration prevention

Condition Assessment of concrete structures

- Damage assessment strategies

- Damage modelling and damage mechanisms

- Condition assessment and damage diagnosis

- Non-destructive testing

Analytical modelling

Concrete repair, rehabilitation and retrofitting

- Compatibility of repair materials

- Repair strategies

Repair modelling

- Corrosion and corrosion protection in concrete repair Physico-mechanical repair methods

- Electrochemical repair methods

- Concrete protection methods
- Life span extension methods Structural Repairs and strengthening

- Structural retrofitting for altered service conditions

- Seismic retrofit

- Repair systems FRP systems

Performance monitoring and health assessment

- Performance testing of repair materials

- Performance of repaired/retrofitted structures Repair performance monitoring

Health monitoring of repaired/retrofitted structures

Repair durability

- Damage prognosis and service life predictions

Reliability and risk assessment

Structural management systems

Case studies

5. Contact :

Conference address: ICCRRR, Department of Civil Engineering, University of Cape Town

Snape Building, Private Bag, Rondebosch, 7701, South Africa

Telephone: +27-21 650 2603,

Fax: + 27-21 6897471

Email: ICCRRR@eng.uct.ac.za

6. Website URL :

http://www.civil.uct.ac.za/iccrrr 